\title{
PERBEDAAN PRESTASI BELAJAR KULIAH DARING MAHASISWA FAKULTAS PSIKOLOGI PADA MASA PANDEMI
}

\author{
Sudjiwanati*
}

\section{${ }^{\star}$ Corresponding Author:}

Universitas Wisnuwardhana Malang

Email:

sudjiwanati02@gmail.com

\begin{abstract}
Abstrak. Masa pandemi merupakan masa perubahan yang sulit di prediksi akan berakhir, pembelajar seluruh dunia hanya menanti masa yang nyata telah tidak ada lagi virus covid-19. Masalahnya adalah tidak semua mahasiswa sebagai pembelajar dapat cepat menangkap kuliah daring selama masa pandemi. Tujuan dari penelitian adalah untuk mengetahui perbedaan prestasi belajar antara mahasiswa laki-laki dan mahasiswa perempuan di fakultas psikologi dalam mengikuti kuliah daring selama masa pandemi. Jumlah sampel yang digunakan adalah 78 orang dengan perincian 37 mahasiswa laki-laki dan 41 mahasiswa perempuan. Alat ukur yang digunakan adalah skala prestasi belajar. Uji reliabilitas Cronbach Alfa terhadap skala prestasi belajar adalah 0,615 $>0,60$. Berdasarkan analisis data menggunakan analisis uji paired sample t-test diperoleh nilai signifikansi $0.024<0.05$ yang berarti bahwa terdapat perbedaan nyata prestasi belajar antara mahasiswa laki-laki dan perempuan selama masa kuliah daring mahasiswa psikologi di masa pandemi. Hasil uji statistik juga menunjukkan bahwa mean prestasi belajar mahasiswa laki-laki 92,7 lebih besar mean mahasiswa perempuan sebesar 89,1. Berdasarkan hasil penelitian maka perlu adanya dukungan dan kerjasama antara dosen dan mahasiswa dalam memahami penggunaan teknologi dan mengatasi kendala-kendala yang terjadi akibat dalam pembelajaran daring.
\end{abstract}

Kata Kunci: Prestasi Belajar, Kuliah Daring, Masa Pandemi

Abstract. The pandemic period is a time of change that is difficult to predict will end, students around the world are only waiting for the real-time that the Covid-19 virus is no longer there. The problem is that not all students as learners can quickly catch online lectures during a pandemic. The study aimed to determine the differences in learning achievement between male students and female students in the psychology faculty in taking online courses during the pandemic. The number of samples used was 78 people with the details of 37 male students and 41 female students. The measuring instrument used is the learning achievement scale. The Cronbach Alfa reliability test on the learning achievement scale was $0.615>0.60$. Based on data analysis using paired sample $t$-test analysis, a significance value of $0.024<0.05$ was obtained, which means that there is a significant difference in learning achievement between male and female students during online college psychology students during the pandemic. The results of statistical tests also show that the mean of male student learning achievement is 92.7 greater than the mean of female students by 89.1. Based on the research results, it is necessary to have support and cooperation between lecturers and students in understanding the use of technology and overcoming the obstacles that occur as a result of online learning.

Keywords: Learning Achievement, Online Lecture, Pandemic Period

\section{PENDAHULUAN}

Masa pendemi merupakan masa sulit bagi semua orang seliuruh dunia baik mulai bayi, anak-anak, remaja, orang dewasa, dan lansia seluruh dunia. Per- masalahan prestasi belajar pada masa pandemi merupakan tantangan bagi pembelajar dalam menyikapi segala urusan yang terkait proses dan hasilnya setelah mempelajari materi yang di pelajari. Prestasi belajar 
merupakan output dari proses belajar yang dinyatakan dengan skor atau nilai. Pencapaian prestasi belajar yang diperoleh mahasiswa dapat diukur dengan metode yang sudah ditetapkan dan dalam jangka waktu tertentu. Penilaian terhadap hasil belajar bukanlah satu-satunya tujuan dari suatu prestasi belajar, tetapi juga peningkatan pemahaman terhadap materi pembelajaran yang diterima oleh mahasiswa.

Efektifitas proses pembelajaran yang diberikan kepada mahasiswa dapat diketahui melalui evaluasi enam bulanan atau per semester. Efektifitas proses belajar akan dapat dilihat dari kemampuan mahasiswa menguasai materi-materi pelajaran yang diberikan. Permasalahan mengenai prestasi belajar pada masa pandemi perlu mendapat perhatian pada berbagai pihak oleh sebab itu menarik untuk dilakukan penelitian. Manfaat yang diharapkan dapat diperoleh dari penelitian antara lain secara teoritis bermanfaat sebagai masukan dalam rangka pengembangan konsep ilmu psikologi, khususnya psikologi perkembangan. Secara praktis bermanfaat secara langsung kepada orangtua siswa dan siswa sendiri dalam memberikan semangat dalam belajar pada masa pandemi.

Berdasarkan Kamus Besar Bahasa Indonesia (KBBI) pengertian prestasi belajar adalah hasil pencapaian dari apa yang telah dilakukan atau dikerjakan (KBBI, 2020). Pengertian prestasi belajar dalam kaitannya dengan proses pendidikan dapat berarti suatu hasil dari proses belajar mengajar yang dapat berupa penguasaan materi pembelajaran, perubahan emosional menjadi lebih matang, atau perubahan perilaku yang dapat diukur melalui metode evaluasi tertentu (Abdullah, 2008). Prestasi belajar juga dapat diartikan sebagai hasil usaha maksimal yang dapat dicapai oleh seseorang dalam kegiatan belajar berdasarkan atas pengukuran tertentu (Ilyas, 2008).

Prestasi belajar menurut (Slameto, 2003, 2010) dapat dipengaruhi oleh faktor-faktor yang dapat dikelompokan sebagai berikut:

a. Faktor Internal

Faktor internal yang dimaksud adalah faktor intrinsik yang dapat dibagi menjadi kondisi fisiologi dan kondisi psikologis:

1) Kondisi Fisiologis Secara Umum

Kondisi fisiologis seseorang dapat mempengaruhi prestasi belajar seseorang. Orang yang memiliki kondisi fisiologi yang baik, sehat jasmaninya, dapat memperoleh hasil belajar yang lebih baik dibandingkan dengan seseorang dengan kondisi fisiologis yang kurang sehat. Kondisi dimana seseorang kekurangan asupan gizi dapat berpengaruh terhadap hasil belajarnya, karena saat kekurangan gizi tubuh akan menjadi mudah lelah, mudah mengan- tuk, dan mengalami kesulitan dalam menerima pelajaran.

\section{2) Kondisi Psikologis}

Belajar pada hakikatnya adalah proses psikologi. Kondisi psikologis seseorang dapat berpengaruh terhadap proses belajarnya. Faktor psikologis dapat dikatakan sebagai faktor dari dalam yang menentukan bagaimana seseorang belajar. Hal tersebut dapat terjadi karena meskipun faktor luar mendukung proses belajar, tetapi apabila kondisi psikologis seseorang kurang mendukung, maka hasil belajarnya menjadi kurang maksimal. Kondisi psikologis yang berpengaruh terhadap proses dan prestasi belajar antara lain: minat, tingkat kecerdasan, motivasi, bakat, dan kemampuan-kemampuan kognitif (Djamarah, 2008).

\section{3) Kondisi Panca Indera}

Disamping kondisi fisiologis umum, kondisi panca indera seseorang juga dapat mempengaruhi hasil dari proses pembelajaran yang dilakukan. Melalui panca indera seseorang dapat melihat, mendengar, merasakan proses pembelajaran yang diberikan.

\section{4) Intelegensi/Kecerdasan}

Intelegensi adalah kemampuan yang umum dari seseroang untuk belajar dan memecahkan suatu permasalahan yang dihadapi. Intelegensi yang kurang dapat menghambat proses pembelajaran, meskipun hal tersebut dapat dimaksimalkan melalui bantuan orang lain dan dengan metode tertentu yang disesuaikan dengan tingkat intelegensi seseorang.

\section{5) Bakat}

Bakat merupakan kemampuan yang unggul dalam suatu bidang tertentu. Bakat yang dimiliki seseorang dibentuk dalam kurun waktu tertentu, dan apabila tidak dikembangkan maka bakat tersebut lama-kelamaan dapat hilang.

\section{6) Motivasi}

Motivasi adalah faktor pendorong internal. Motivasi berperan penting dalam menumbuhkan gairah, memberikan semangat, dan menciptakan rasa senang dalam belajar. Motivasi dalam belajar terutama motivasi yang berasal dalam diri sendiri perlu terus diusahakan agar lebih termotivasi untuk belajar. Mahasiswa yang rendah motivasi instrinsiknya memerlukan dorongan dari luar yaitu motivasi ekstrinsik untuk meningkatkan motivasi belajarnya. 


\section{b. Faktor Eksternal}

Faktor eksternal menurut Djamarah (2008) sering disebut dengan faktor ekstrinsik yang berasal dari luar diri seseorang baik dari lingkungan sosial maupun lingkungan yang lain yang dapat mendukung keberhasilan belajar seseorang.

1) Faktor Lingkungan

\section{a) Lingkungan Alami}

Lingkungan alami merupakan lingkungan alam yang terdapat disekitar seseorang hidup. Lingkungan alami yang mendukung seperti keadaan udara, iklim, suhu udara maupun kelembapan yang sesuai dapat mendukung keberhasilan belajar seseorang.

\section{b) Lingkungan Sosial}

Lingkungan sosial merupakan lingkungan hasil interaksi dengan sesama manusia maupun representasinya. Lingkungan sosial yang mendukung seperti kondisi tempat tinggal yang tenang akan membuat seseorang lebih mudah untuk belajar dari pada ditempat yang ramaidan bising.

\section{2) Faktor Instrumental}

Faktor instrumental merupakan faktor pendukung yang ditujukan untuk mencapai hasil belajar yang diharapkan. Faktor instrumental merupakan sarana yang dapat mendukung proses belajar dapat berupa:

a) Perangkat keras (hardware) misalnya gedung, ruangan kelas, sarana dan prasarana pembelajaran, ruangan dan alat-alat praktikum, dan lain sebagainya.

b) Perangkat lunak (software) seperti metode pembelajaran, bahan ajar, kurikulum, program-program komputer. (Djamarah, 2008)

Faktor-faktor lain yang mendukung prestasi belajar menurut Syah (2011) terbagi menjadi 3 faktor, yaitu: 1) faktor internal, yang terdiri atas keadaan jasmani dan rohani siswa, 2) faktor eksternal yaitu kondisi lingkungan sekitar, dan 3) faktor pendekatan belajar mempelajari materi pembelajaran yang diterima. (Syah, 2011).

Prestasi belajar mempunyai tiga aspek, yaitu aspek kognitif, aspek afektif dan aspek psikomotorik ((Djamarah, 2008).

\section{1) Aspek Kognitif}

Aspek kognitif merupakan aspek yang berkenaan dengan bagaimana seseorang melakukan pengenalan baru (merekam) atau proses mengingat kembali sesuatu yang sudah dipelajari (menghafal), memahami sesuatu, mengaplikasikan hasil belajarnya, menganalisis suatu masalah, dan kemampuan mengevaluasi segala sesuatu yang telah dilakukan.

\section{2) Aspek Afektif}

Aspek afektif merupakan aspek yang berhubungan dengan kemampuan bagaimana seseorang membangkitkan minat, sikap/emosi seseorang, penghormatan (kepatuhan) terhadap nilai atau norma yang berlaku di masyarakat.

\section{3) Aspek Psikomotor}

Aspek psikomotor merupakan aspek yang berhubungan dengan keterampilan atau menunjukkan gerak (skill).

Berdasarkan uraian diatas, menarik untuk diteliti bagaimana faktor-faktor prestasi belajar dapat mempengaruhi prestasi belajar mahasiswa terlebih pada masa pandemi, Penelitian yang dilakukan bertujuan untuk melihat bagaimana prestasi belajar mahasiswa psikologi laki-laki dan perempuan selama mengikuti kuliah daring di masa pandemi. Hipotesis penelitian ini adalah bahwa terdapat perbedaan prestasi belajar mahasiswa psikologi antara laki-laki dan perempuan pada masa pandemi.

\section{METODE}

Variabel dalam penelitian adalah prestasi belajar dan populasi dalam penelitian ini adalah mahasiswa psikologi Unidha yang berdomisili di Malang pada masa pandemi sejumlah 100 orang laki dan perempuan. Teknik pengambilan sampel menggunakan simple random sampling dengan cara pengambilan sampel berdasarkan tabel Isaac Michael pada tingkat kesalahan $5 \%$ dengan teknik undian berdasarkan nomor absen mahasiswa. Jumlah sampel yang digunakan adalah 78 orang dengan pembagian 39 mahasiswa laki-laki dan 39 mahasiswa perempuan.

Definisi operasional guna memberi batasan yang jelas mengenai pengertian dari variabel yang digunakan dalam penelitian, maka definisi operasionalnya adalah prestasi belajar merupakan hasil yang telah dicapai siswa berdasarkan evaluasi proses pembelajaran yang diterima dalam jangka waktu tertentu.

Metode pengumpulan data menggunakan alat ukur skala prestasi belajar, yaitu metode pengumpulan data dengan mengisi daftar peryataan-pernyataan yang jawabanya telah disediakan. Metode ini memiliki keuntungan besar yaitu dapat dilakukan pada seluruh responden yang menjadi sampel dalam waktu singkat dan dapat dilakukan bersama-sama. Skala prestasi belajar disusun berdasarkan teori yang diungkapkan oleh Slameto $(2003,2010)$ tentang faktor-faktor yang mempengaruhi prestasi belajar 
dapat dikelompokkan sebagai berikut:

\section{a. Faktor Internal}

Faktor-faktor yang berhubungan seluruh kondisi internal baik kondisi fisik maupun mental atau psikis yang mencangkup minat, kecerdasan, bakat, motivasi, dan lain-lain.

\section{b. Faktor Eksternal}

Faktor-faktor yang berasal dari luar diri individu itu sendiri. Faktor dari luar diri individu yang dapat berpengaruh terhadap prestasi belajar yaitu lingkungan sosial dan juga lingkungan lain disekitar individu.

Penyusunan skala prestasi belajar penilaiannya disusun berdasarkan skala Likert. Alternatif jawaban yang diberikan pada pernyataan dan setiap item akan diberikan skor sesuai dengan nilai skala kategori jawaban yang diberikan dengan penilaian ada 4 pilihan jawaban yaitu SS (Sangat Setuju), TS (Tidak Setuju), S (Setuju) dan STS (Sangat Tidak Setuju). Jumlah skala prestasi belajar yang digunakan adalah sebanyak 30 item.

\section{HASIL DAN PEMBAHASAN}

Hasil

Hasil penelitian berdasarkan uji statistik paired sample t-test yang dilakukan diperoleh nilai signifikansi 0,024<0,05 yang berarti bahwa hipotesis (H1) yang berbunyi ada perbedaan prestasi belajar antara mahasiswa psikologi laki-laki dan perempuan dalam kuliah daring di masa pandemi diterima. Hasil uji paired sample test dapat dilihat pada tabel 1 .

Tabel 1. Hasil Uji Paired Samples Test

\begin{tabular}{|c|c|c|c|c|c|}
\hline & & Mean & $\mathrm{t}$ & $\mathrm{df}$ & $\operatorname{Sig}(2$-tailed) \\
\hline $\begin{array}{l}\text { Pair } \\
1\end{array}$ & $\begin{array}{l}\text { Laki-laki } \\
\text { Perempuan }\end{array}$ & 3.66667 & 2.350 & 38 & .024 \\
\hline
\end{tabular}

Berdasarkan uji statistik juga diketahui bahwa kelompok mahasiswa laki-laki memiliki nilai mean $92.7>89.1$ dibandingkan kelompok mahasiswa perempuan. Data tersebut menunjukkan bahwa prestasi belajar mahasiswa laki-laki lebih baik dibandingkan prestasi belajar mahasiswa perempuan dalam kuliah daring di masa pandemi. Hasil uji statistik perbandingan rata-rata dapat dilihat pada tabel 2 .

Tabel 2. Perbandingan Nilai Rata-rata Antar Kelompok Mahasiswa

\begin{tabular}{llcccl}
\hline & Mean & $\mathrm{N}$ & $\begin{array}{l}\text { Std. De- } \\
\text { viation }\end{array}$ & $\begin{array}{l}\text { Std. } \\
\text { Mean }\end{array}$ \\
\hline Pair 1 & Laki-laki & 92.7 & 39 & 7.71857 & 1.23596 \\
& Perempuan & 89.1 & 39 & 5.01025 & .80228 \\
\hline
\end{tabular}

\section{Pembahasan}

Prestasi belajar di bidang pendidikan diperoleh berdasarkan hasil dari evaluasi yang dilakukan dalam jangka waktu tertentu. Evaluasi yang dilakukan terhadap proses pembelajaran yang dijalani oleh mahasiswa dilakukan dengan menggunakan metode pengukuran terhadap faktor kognitif, afektif dan psikomotor. Hasil dari evaluasi dan penilaian terhadap hasil dari proses pembelajaran dapat dinyatakan dalam bentuk simbol, huruf ataupun kalimat yang menceritakan hasil yang sudah dicapai oleh setiap mahasiswa.

Menurut Winkel (2004), prestasi belajar dapat dikatakan sebagai bukti dari keberhasilan dan pencapaian oleh seorang mahasiswa dalam kegiatan pembelajaran. Pencapaian prestasi belajar setiap individu pada dasarnya berbeda, karena disebabkan adanya faktor internal dan faktor eksternal yang pengaruhnya berbeda pada masing-masing individu. Perpaduan antara faktor internal dan eksternal yang dapat memberikan hasil yang berbeda-beda terhadap prestasi belajar setiap individu (Muharam et al., 2019; Winkel, 2004).

Berdasarkan hasil penelitian diperoleh hasil bahwa prestasi belajar antara mahasiswa laki-laki dan perempuan berbeda, dimana prestasi belajar mahasiswa laki-laki lebih baik dari prestasi belajar mahasiswa perempuan dalam mengikuti perkuliahan secara daring selama masa pandemi. Hasil penelitian ini sesuai dengan hasil penelitian yang dilakukan oleh Ahmad dan Sehabuddin (2017) yang menunjukkan bahwa terdapat perbedaan yang signifikan terhadap prestasi belajar siswa berdasarkan gender. Dalam penelitian ini prestasi belajar siswa perempuan lebih baik dari pada prestasi belajar siswa laki-laki (Ahmad \& Sehabuddin, 2017). Penelitian lain yang dilakukan oleh Rahmi, et.al (2018) juga menunjukkan bahwa prestasi belajar siswa perempuan dalam mata pelajaran matematika lebih unggul dibandingkan dengan siswa laki-laki dikarenakan siswa perempuan lebih rajin masuk dan teliti dibandingkan dengan siswa laki-laki (Rahmi et al., 2018).

Prestasi belajar yang lebih baik pada mahasiswa laki-laki dibandingkan dengan mahasiswa perempuan dalam kuliah daring selama masa pandemi pada penelitian ini dapat disebabkan karena mahasiswa laki-laki lebih siap dalam menghadapi perkuliahan secara daring selama masa pandemi dibandingkan dengan mahasiswa perempuan. Salah satu faktor yang dapat berpengaruh terhadap prestasi belajar adalah kesiapan belajar yang merupakan kemampuan yang dimiliki oleh seseorang untuk mencari pengetahuan berdasarkan dari pengalamannya (Darsono, 2000; 
Sinta B, 2017). Mahasiswa laki-laki memiliki kecenderungan lebih menyukai penggunaan teknologi dalam pembelajaran dibandingkan dengan mahasiswa perempuan (Kadijevich, 2000; Yau \& Cheng, 2012)

Darsono (2000) mengemukakan bahwa dalam proses belajar ada prinsip-prinsip yang penting yang harus dipenuhi agar mencapai prestasi belajar yang baik. Prinsip-prinsip belajar yang perlu diperhatikan adalah: kesiapan belajar, perhatian, motivasi, keaktifan mahasiswa, mengalami sendiri proses pembelajaran, pengulangan terhadap materi pembelajaran, mempelajari materi pelajaran yang menantang, balikan dan penguatan, serta perbedaan individual (Darsono, 2000).

Prestasi belajar pada mahasiswa psikologi yang mengikuti proses pembelajaran secara daring pada masa pandemi disebabkan oleh faktor internaldan eksternal. Faktor internal yang dapat mempengaruhi prestasi belajar mahasiswa adalah motivasi untuk beradaptasi terhadap perubahan pembelajaran yang lebih pada pembelajaran secara daring. Faktor eksternal yang berpengaruh terhadap prestasi belajar adalah kondisi pandemi yang saat ini terjadi. Pemberian motivasi kepada para mahasiswa oleh dosen agar tetap bersemangat untuk terus belajar di tengah-tengah masa pandemi adalah salah satu hal yang dapat dilakukan dalam membantu mahasiswa dalam meningkatkan prestasi belajarnya. Pemberian dukungan sosial baik dari teman atau dosen dalam membantu mahasiswa memahami penggunaan teknologi dan mengatasi kendala-kendala yang terjadi akibat dalam pembelajaran daring dapat juga menjadi salah satu cara untuk meningkatkan prestasi bealajar siswa (Limbong, 2020).

\section{KESIMPULAN DAN SARAN Kesimpulan}

Berdasarkan hasil penelitian yang telah dilakukan pada mahasiwa Psikologi Malang diketahui bahwa terdapat perbedaan prestasi belajar yang signifikan antara laki-laki dan perempuan. Prestasi belajar pada mahasiswa psikologi laki-laki lebih tinggi dibandingkan prestasi belajar mahasiswa perempuan.

Prestasi belajar mahasiswa psikologi dalam mengikuti perkuliahana secara daring pada masa pandemi menunjukkan adanya pengaruh dari penggunaan teknologi selama perkuliahan daring. Pemberian motivasi dan kerjasama baik antar mahasiswa dan dosen untuk memahami penggunaan teknologi selama pembelajaran secara daring dapat mengatasi kendala-kendala yang terjadi akibat perubahan dalam metode pembelajaran sehingga dapat memperbaiki prestasi belajar mahasiswa.

\section{Saran}

Mahasiswa disarankan saling bekerja sama dalam memahami penggunaan teknologi dalam pembelajaran secara daring, sehingga dapat memaksimalkan fungsi teknologi tersebut.

Fakultas Psikologi di Malang sebagai instansi pendidikan dianjurkan mampu memberikan kontribusi baru dengan cara melakukan pelatihan, seperti pelatihan kepribadian yang berhubungan dengan prestasi belajar dan juga pemanfaatan media belajar berbasis teknologi . Sehingga mahasiswa memiliki kesiapan, ketaatan terhadap kegiatan belajar, ketaatan terhadap mengerjakan tugas pelajaran dan ketaatan terhadap kegiatan belajar di rumah, agar mahasiswa mampu memproses dirinya dalam mengembangkan prestasi belajar menjadi lebih baik.

Orang tua disarankan untuk mendidik anak dalam segala aspek kepribadian dalam kehidupan sehari-hari dan pemanfaatan teknologi dalam pendidikan, terutama untuk memperoleh prestasi belajar yang baik sehingga anak semakin termotivasi dalam mengembangkan prestasi belajarnya terlebih pada masa pandemi.

Peneliti selanjutnya adalah dengan cara mengembangkan teori-teori variabel penelitian tentang prestasi belajar dengan variabel lain pada penelitian selanjutnya. Mengembangkan instrument yang dapat digunakan pada populasi dan sampel penelitian yang berbeda.

\section{DAFTAR PUSTAKA}

Abdullah. (2008). Prestasi Belajar. Universitas Islam Negeri Malang.

Ahmad, A., \& Sehabuddin, A. (2017). Komparasi Prestasi Belajar Matematika Siswa Berdasarkan Gender. JTAM | Jurnal Teori Dan Aplikasi Matematika, 1(1), 15. https://doi.org/10.31764/ jtam.v1il.4

Darsono, M. (2000). Belajar dan Pembelajaran. IKIP Semarang Press.

Djamarah. (2008). Psikologi Belajar. PT. Rineka Cipta. Ilyas. (2008). Fungsi dan Pengukuran Prestasi Belajar. Pustaka Pelajar.

Kadijevich, D. (2000). Gender Differences in Computer Attitude among Ninth-Grade Students. Journal of Educational Computing Research, 22(2), 145-154. https://doi.org/10.2190/K4U2-PWQGRE8L-UV90

KBBI. (2020). Kamus Besar Bahasa Indonesia. https:// kbbi.web.id/prestasi

Limbong, A. (2020). Pengaruh Model Pembelajaran Daring Akibat Pandemi Covid-19 Terhadap Prestasi Belajar Mahasiswa UNAI pada Semester 
Genap 2019/2020. TeIKa, 10, 161-168. https:// doi.org/10.36342/teika.v10i2.2386

Muharam, L. O., Ihjon, I., Hijrah, W. O., \& Samiruddin, T. (2019). The effect of teaching style on students' motivation and academic achievement: Empirical evidence from public senior high school in konawe selatan regency. International Journal of Scientific and Technology Research, 8(9), 1934-1938.

Rahmi, H., Yunus, J., \& Zubaidah, T. (2018). Prestasi Belajar Matematika Siswa berdasarkan Gender di Kelas XI SMA Inshafuddin Banda Aceh. Jurnal Ilmiah Mahasiswa Pendidikan Matematika, 3(2), 30-34.

Sinta B, V. (2017). Pengaruh Kesiapan Belajar Terhadap Hasil Belajar Mata Pelajaran Ekonomi Kelas X Di SMA Bina Jaya Palembang. Jurnal Ilmiah Pendidikan Dan Ekonomi, 1(1), 11-20.

Slameto. (2003). Belajar dan faktor-faktor yang Mempengaruhinya. PT. Rineka Cipta.

Slameto. (2010). Belajar dan faktor-faktor yang Mempengaruhinya. PT. Rineka Cipta.

Syah, M. (2011). Psikologi Pendidikan. PT. Remaja Rosdakarya.

Winkel, W. S. (2004). Psikologi Pendidikan dan Evaluasi Belajar. PT. Gramedia Pustaka Utama.

Yau, H. K., \& Cheng, A. L. F. (2012). Gender Difference of Confidence in Using Technology for Learning. The Journal of Technology Studies, 38(2), 74-79. https://doi.org/10.21061/jots.v38i2.a.2 